\title{
Statistical optimization of fibrinolytic enzyme production by Pseudoalteromonas sp. IND11 using cow dung substrate by response surface methodology
}

\author{
Ponnuswamy Vijayaraghavan ${ }^{*}$ and Samuel Gnana Prakash Vincent
}

\begin{abstract}
Fibrinolytic enzymes are agents that dissolve fibrin clots. These fibrinolytic agents have potential use to treat cardiovascular diseases, such as heart attack and stroke. In the present article, a fibrinolytic enzyme producing Pseudoalteromonas sp. IND11 was isolated from the fish scales and optimized for enzyme production. Cow dung was used as a substrate for the production of fibrinolytic enzyme in solid-state culture. A two-level full factorial design was used for the screening of key ingredients while further optimization was carried out using the central composite design. Statistical analysis revealed that the second-order model is significant with model $F$-value of 6.88 and $R^{2}$ value of 0.860 . Enzyme production was found to be high at pH 7.0, and the supplementation of $1 \%(\mathrm{w} / \mathrm{W})$ maltose and $0.1 \%(\mathrm{w} / \mathrm{W})$ sodium dihydrogen phosphate enhanced fibrinolytic enzyme production. The optimization of process parameters using response surface methodology resulted in a three-fold increase in the yield of fibrinolytic enzyme. This is the first report on production of fibrinolytic enzyme using cow dung substrate in solid-state fermentation.
\end{abstract}

Keywords: Fibrinolytic enzymes; Response surface methodology; Pseudoalteromonas sp. IND11; Cow dung; Solid-state fermentation

\section{Introduction}

Fibrin is the main component of the blood clot, and it is normally formed from fibrinogen by the action of thrombin (EC. 3. 4. 21. 5). The accumulation of fibrin in the blood vessels usually results in thrombosis. Thrombus in blood vessels or in a chamber of the heart leads to myocardial infarction and other cardiovascular diseases (CVDs). For thrombolytic therapies, both injection and oral administration of thrombolytic agents have been extensively investigated. Based upon their mechanism of activation of the fibrinolytic system, fibrinolytic agents are classified into two types. One is plasminogen activator such as tissue-type plasminogen activator (t-PA) (Collen and Lijnen 2004) and urokinase (Duffy 2002). The other one is plasmin-like fibrinolytic

\footnotetext{
*Correspondence: venzymes@gmail.com

International Centre for Nanobiotechnology, Centre for Marine Science and Technology, Manonmaniam Sundaranar University, Rajakkamangalam-629 502, Kanyakumari District, Tamil Nadu, India
}

enzymes, which can directly degrade the fibrin in blood clots, thereby dissolving the thrombi rapidly. Examples of that type of protease are nattokinase (Sumi et al. 1987) and lumbrokinase (Mihara et al. 1991). Urokinase and t-PA are still widely used in thrombolytic therapy, but these agents have some undesirable side effects when orally administered and are expensive also (McGrath et al. 1985; Bode et al. 1996). Therefore, the search for safer thrombolytic agents from other sources is ongoing.

Microbial fibrinolytic protease is considered as a potent fibrinolytic agent to treat CVDs (Mine et al. 2005). Many thrombolytic agents have been identified and characterized from different sources (Fujita et al. 1993; Peng et al. 2003; Jeong et al. 2004; Wang et al. 2006). Although microbial fibrinolytic enzymes have been extensively studied, only few reports are available concerning statistical medium optimization (Liu et al. 2005; Deepak et al. 2010; Mahajan et al. 2012). In recent years, an attempt was made to isolate a potent fibrinolytic enzyme producing organism from 
marine environment (Mahajan et al. 2012). The newly established genus Pseudoalteromonas contains numerous species that synthesize biologically active molecules (Holmstrom and Kjelleberg 1999). The protease production of Pseudoalteromonas sp. has been reported by various researchers (Porro et al. 2003; Olivera et al. 2007; Xiong et al. 2007; Wang et al. 2008). Thrombolytic enzyme secreting marine bacteria Alteromonas piscicida was isolated by Demina et al. (1990). Hence, it is worthwhile to screen this Pseudoalteromonas sp. for fibrinolytic enzyme secretion and statistical optimization for enzyme production.

In the present article, solid-state fermentation (SSF) was employed for the production of fibrinolytic enzyme using cow dung substrate. Cattle manure consists of cellulose (35.4\%), hemicelluloses (32.6\%), ash (13.3 - 13.4\%) and nitrogen $(1.2-1.6 \%)$ (Misra et al. 2003). Cow dung substrate was effectively used for the production of alkaline protease recently in SSF (Vijayaraghavan and Vincent 2012; Vijayaraghavan et al. 2012). In enzyme bioprocess, designing a suitable medium for maximum production is of critically important because the medium components significantly affect the product yield. Considering its cheap cost and availability, an attempt was made to use cow dung as a substrate for the production of fibrinolytic enzyme from Pseudoalteromonas sp. IND11. The traditional one-at-a-time optimization strategy is simple and easy, but it fails frequently. Statistical experimental design provides an efficient approach to optimize the medium components. Fractional factorial design (FFD) is especially suitable to account for the interactions and identify the most significant components in the medium formula. A combination of factors generating a certain optimum response can be identified through factorial design and the use of response surface methodology (RSM). The statistical method is more satisfactory and effective than other classical one-at-a-time optimization strategies because it can study many variables simultaneously with a lower number of observations, thus saving time and cost (Montogomery 2001). RSM is a well-known method applied in the optimization of medium constituents and other critical variables responsible for the production of biomolecules (Hong et al. 2004) and enzymes (Long et al. 2009; Zhang et al. 2012; Farid et al. 2013).

The aim of this work was to optimize the fermentation medium by statistical approach to increase fibrinolytic enzyme production by Pseudoalteromonas sp. using cow dung, which is a low cost substrate.

\section{Methods}

\section{Screening and identification of a fibrinolytic enzyme producing Pseudoalteromonas sp. IND11}

Pseudoalteromonas sp. IND11 producing a fibrinolytic enzyme was isolated along with other bacteria from the fish scales in Kanyakumari, India. Primary screening was carried out using skimmed milk agar plates. The sample was homogenized and platted on skimmed milk agar plates (peptone, $5 \mathrm{~g} / \mathrm{L}$; beef extract, $1.5 \mathrm{~g} / \mathrm{L}$; yeast extract, $1.5 \mathrm{~g} / \mathrm{L}$; sodium chloride, $5 \mathrm{~g} / \mathrm{L}$; agar, $15 \mathrm{~g} / \mathrm{L}$; skim milk, $10 \mathrm{~g} / \mathrm{L}$ ). All plates were incubated at $37^{\circ} \mathrm{C}$ for $24 \mathrm{~h}$, and a total of nine positive isolates were obtained based on their morphological and cultural characteristics. All nine organisms were cultured in nutrient broth medium (peptone, $5 \mathrm{~g} / \mathrm{L}$; beef extract, $1.5 \mathrm{~g} / \mathrm{L}$; yeast extract, $1.5 \mathrm{~g} / \mathrm{L}$; sodium chloride, $5 \mathrm{~g} / \mathrm{L}$; and casein, $10 \mathrm{~g} / \mathrm{L}$ ) and incubated at $37^{\circ} \mathrm{C}$ in a shaker $(150 \mathrm{rpm})$ for $48 \mathrm{~h}$. These isolates were further screened using fibrin plates. The cell-free extracts $(15 \mu \mathrm{l})$ were dropped into the well of fibrin plate ( $\mathrm{pH} 7.4)$. The single strain showing the largest halo zone on fibrinagarose plate was selected and further identified. Various biochemical tests of the isolate Pseudoalteromonas sp. IND11 were done to identify it according to the "Bergey's Manual of Systematic Bacteriology" (Sneath 1986) and by $16 \mathrm{~S}$ rDNA sequencing. The genomic DNA of the isolate was extracted using genomic DNA extraction kit (QIAGEN, Germany) per manufacturer's instructions. Amplification of the 16S rDNA was performed with universal primers $27 \mathrm{~F}$ (5'-AGAGTTTGATCMTGGCTAG-3') and 1492R (5'-ACGGGCGGTGTGTRC-3'), using a research gradient Peltier Thermal cycler machine PTC-225 (USA). PCR products were isolated from the agarose gel using a QIA quick gel extraction kit (QIAGEN, Germany) and sequenced. A sequence similarity search was performed using BLAST in the NCBI database. The 612 bp $16 \mathrm{~S}$ rDNA sequence of strain has been submitted to Genbank database and assigned accession number KF683956.

\section{Assay of fibrinolytic activity}

Fibrinolytic activity was measured by the hydrolysis of fibrin according to the method described by Ansen (1939) with some modifications. The incubation mixture contained $2.5 \mathrm{ml}$ of $1.2 \%$ fibrin (w/v), $2.5 \mathrm{ml}$ of $0.1 \mathrm{M}$ Tris- $\mathrm{HCl}$ (0.01 $\left.\mathrm{M} \mathrm{CaCl}_{2}, \mathrm{pH} 7.8\right)$, and a suitable amount of enzyme. The incubation was carried out at $37^{\circ} \mathrm{C}$ for $30 \mathrm{~min}$, and the reaction was stopped by adding $5 \mathrm{ml}$ of $0.11 \mathrm{M}$ trichloroacetic acid containing $0.22 \mathrm{M}$ sodium acetate and $0.33 \mathrm{M}$ acetic acid. The absorbance of the supernatant was measured at $275 \mathrm{~nm}$. A fibrinolytic unit was defined as the amount of enzyme that gave an increase in absorbency at $275 \mathrm{~nm}$ equivalent to $1 \mu \mathrm{g}$ of tyrosine per minute at $37^{\circ} \mathrm{C}$. The total protein content determination was performed by Lowry et al. (1951).

\section{Optimization for fibrinolytic enzyme production by one-variable-at-a-time approach}

Cow dung was collected locally and dried for one week (sun drying). It was powdered using a mixer grinder, sieved and stored at room temperature for further use. Cow dung was used as the substrate. SSF was carried out in a $100 \mathrm{ml}$ 
Erlenmeyer conical flask containing $2 \mathrm{~g}$ substrate. In the present article, the requirement of medium components including various carbon $(1 \%[\mathrm{w} / \mathrm{w}]$, glucose, sucrose, maltose, xylose, trehalose, and starch) and nitrogen sources $(1 \%[\mathrm{w} / \mathrm{w}]$, yeast extract, urea, casein, gelatin, beef extract, and peptone) and inorganic salts $(1 \%[\mathrm{w} / \mathrm{w}]$, ammonium chloride, ferrous sulfate, disodium hydrogen phosphate, calcium chloride, sodium nitrate, sodium dihydrogen phosphate, and ammonium sulfate) were optimized. The physical factors such as fermentation period (24-96 h), $\mathrm{pH}(5-10)$, moisture $(80 \%-160 \%)$, and inoculum $(3 \%-15 \%)$ were also evaluated before being subjected to statistical optimization. Cow dung substrate was moistened with tris buffer ( $\mathrm{pH} 8,0.1 \mathrm{M})$ at $100 \%$ level and was treated as the control. The contents were sterilized and inoculated with $0.2 \mathrm{ml}$ of $18 \mathrm{~h}$ grown culture broth $(0.983 \mathrm{OD}$ at $600 \mathrm{~nm})$ under sterile conditions. The enzyme was extracted from cow dung using $20 \mathrm{ml}$ double distilled water by shaking on a rotary shaker $(150 \mathrm{rpm})$ for $30 \mathrm{~min}$. This was centrifuged at $10000 \mathrm{rpm}$ for $10 \mathrm{~min}$ at $4{ }^{\circ} \mathrm{C}$ and the clear supernatant was used as the crude enzyme.

\section{Evaluation of significant components with two-level full factorial design}

A two-level full factorial design $\left(2^{5}\right)$ was employed to find the key ingredients that affect fibrinolytic enzyme production. The important physical parameters ( $\mathrm{pH}$ and moisture) and nutrient factors (maltose, casein, and sodium dihydrogen phosphate) were evaluated by statistical method. The other factors such as fermentation period and inoculum were kept at optimum level. Based on two-level full factorial design, each factor was examined at two levels ( -1 for low level and +1 for high level). The variables and the levels were described in Table 1. Twolevel full factorial designs were based on the following first-order polynomial model:

$$
\begin{gathered}
Y=\alpha_{0}+\sum \alpha_{i} x_{i}+\sum \alpha_{i j} x_{i} x_{j}+\sum \alpha_{i j k} x_{i} x_{j} x_{k} \\
i \quad i j \quad i j k \\
+\sum \alpha_{i j k l} x_{i} x_{j} x_{k} x_{l}+\sum \alpha_{i j k l m} x_{i} x_{j} x_{k} x_{l} x_{m} \\
i j k l \quad i j k l m
\end{gathered}
$$

Table 1 Variables selected for 2-level full factorial design

\begin{tabular}{llll}
\hline & & \multicolumn{2}{c}{ Coded levels } \\
\cline { 3 - 4 } Factors & Units & $\mathbf{- 1}$ & $\mathbf{+ 1}$ \\
\hline A-pH & $\%$ & 8 & .10 \\
B-Moisture & $\%$ & 80 & 120 \\
C-Maltose & $\%$ & 0.1 & 1.0 \\
D-Casein & $\%$ & 0.1 & 0.5 \\
E-NaH $\mathrm{PO}_{4}$ & & 0.05 & 0.25 \\
\hline
\end{tabular}

where $Y$ is the response (fibrinolytic activity); $\alpha_{i j}, \alpha_{i j k}$, $\alpha_{i j k l}$, and $\alpha_{i j k l m}$ were the $i j$ th, $i j k$ th, $i j k l$ th, and $i j k l m$ th interaction coefficients, respectively; $\alpha_{\mathrm{i}}$ was the $i$ th linear coefficient; and $\alpha_{0}$ was an intercept.

Fibrinolytic enzyme assay was carried out in duplicates, and the average of these experimental values was taken as response $Y$ (Table 2). The statistical software "DesignExpert 8.0" (StatEase Inc., Minneapolis, USA) was used to analyze the experimental results. The factors that affect fibrinolytic enzyme production significantly $(p<0.05)$ were further optimized by central composite design (CCD)

\begin{tabular}{|c|c|c|c|c|c|c|}
\hline Run & $\mathrm{pH}$ & Moisture & Maltose & Casein & $\mathrm{NaH}_{2} \mathrm{PO}_{4}$ & $\begin{array}{l}\text { Enzyme } \\
\text { activity (U/ml) }\end{array}$ \\
\hline 1 & 1 & -1 & 1 & 1 & 1 & 151 \\
\hline 2 & -1 & -1 & -1 & -1 & -1 & 638 \\
\hline 3 & 1 & 1 & -1 & 1 & -1 & 274 \\
\hline 4 & -1 & 1 & -1 & 1 & 1 & 1388 \\
\hline 5 & -1 & 1 & -1 & -1 & -1 & 1118 \\
\hline 6 & 1 & -1 & -1 & -1 & 1 & 521 \\
\hline 7 & 1 & -1 & -1 & -1 & -1 & 398 \\
\hline 8 & -1 & 1 & 1 & -1 & -1 & 844 \\
\hline 9 & -1 & 1 & -1 & 1 & -1 & 404 \\
\hline 10 & -1 & 1 & -1 & -1 & 1 & 1029 \\
\hline 11 & 1 & 1 & 1 & -1 & -1 & 638 \\
\hline 12 & -1 & -1 & 1 & -1 & 1 & 631 \\
\hline 13 & 1 & 1 & 1 & 1 & -1 & 645 \\
\hline 14 & -1 & -1 & -1 & -1 & 1 & 617 \\
\hline 15 & 1 & 1 & -1 & 1 & -1 & 899 \\
\hline 16 & -1 & -1 & 1 & 1 & -1 & 576 \\
\hline 17 & 1 & -1 & -1 & 1 & -1 & 761 \\
\hline 18 & -1 & -1 & -1 & 1 & 1 & 652 \\
\hline 19 & 1 & -1 & -1 & 1 & -1 & 727 \\
\hline 20 & 1 & 1 & 1 & -1 & 1 & 384 \\
\hline 21 & 1 & -1 & -1 & 1 & 1 & 684 \\
\hline 22 & -1 & 1 & 1 & -1 & 1 & 727 \\
\hline 23 & -1 & 1 & 1 & 1 & -1 & 576 \\
\hline 24 & -1 & 1 & 1 & 1 & 1 & 912 \\
\hline 25 & 1 & 1 & -1 & -1 & 1 & 713 \\
\hline 26 & 1 & -1 & 1 & -1 & 1 & 350 \\
\hline 27 & 1 & 1 & -1 & 1 & 1 & 363 \\
\hline 28 & -1 & -1 & 1 & 1 & 1 & 1160 \\
\hline 29 & 1 & -1 & 1 & 1 & -1 & 1251 \\
\hline 30 & 1 & 1 & 1 & 1 & 1 & 89 \\
\hline 31 & -1 & -1 & 1 & -1 & -1 & 748 \\
\hline 32 & 1 & -1 & 1 & -1 & -1 & 562 \\
\hline
\end{tabular}
and RSM.

Table 2 Experimental design and results of the two level $\left(2^{5}\right)$ full factorial design 


\section{Statistical optimization of fibrinolytic enzyme production in SSF by CCD and RSM}

CCD was employed to optimize the fermentation conditions, namely, $\mathrm{pH}$, maltose, and sodium dihydrogen phosphate at five levels $(-\alpha,-1,0,+1,+\alpha)$ (Table 3$)$. The CCD contains a total of 20 experimental runs (8 factorial, 6 central, and 6 axial points). The experiments were conducted in duplicates, and the mean value $(\mathrm{U} / \mathrm{ml})$ of fibrinolytic activity was taken as the response $(Y)$ (Table 4). The statistical software "Design-Expert 8.0" (StatEase) was used to analyze the experimental results. The experimental results of CCD were fitted with a second-order polynomial equation as shown below:

For a three-factor system, the second-order polynomial equation is as follows:

$$
\begin{array}{ccc}
3 \quad 3 \quad & 3 \\
Y=\beta_{0}+\Sigma \beta_{i} X_{i}+\Sigma \beta_{i i} X_{i}^{2}+\Sigma \beta_{i j} X_{i j} \\
i=1 \quad i=1 \quad i j=1
\end{array}
$$

where $Y$ is the response; $\beta_{0}$ is the offset term; and $\beta_{i}, \beta_{i i}$ and $\beta_{i j}$ were the coefficients of linear terms, square terms, and coefficients of interactive terms, respectively. $X_{i}^{\prime}$ 's were $\mathrm{A}, \mathrm{B}$, and $\mathrm{C} ; X_{i j}$ 's were $\mathrm{AB}, \mathrm{AC}$, and $\mathrm{BC}$ (A-coded value of $\mathrm{pH}$; $\mathrm{B}$-coded value of maltose; $\mathrm{C}$-coded value of sodium dihydrogen phosphate).

\section{Validation of the experimental model}

To validate the model equation, experiments were conducted in triplicates for fibrinolytic enzyme production under optimum conditions predicted by the model.

\section{Results and discussion}

\section{Novel compounds from the marine microbes}

Marine organisms known to produce a diverse spectrum of novel metabolites are an untapped source for the discovery of new bioactive compounds (Mahajan et al. 2012). Further, it is believed that sea water, which is saline in nature and chemically closer to the human blood plasma, could provide biomolecules, in particular enzymes that could have lower or no toxicity or side effects when used for therapeutic applications (Sabu 2003). Recently many researchers had focused their efforts on isolating and screening of microorganisms for enzyme production with

Table 3 The independent variables and their levels for the central composite experimental design

\begin{tabular}{|c|c|c|c|c|}
\hline Run & $\mathrm{pH}$ & Maltose & $\mathrm{NaH}_{2} \mathrm{PO}_{4}$ & $\begin{array}{l}\text { Enzyme } \\
\text { activity }(\mathrm{U} / \mathrm{ml})\end{array}$ \\
\hline 1 & 0 & 0 & 0 & 1028 \\
\hline 2 & 0 & 0 & 0 & 1276 \\
\hline 3 & 1 & -1 & -1 & 910 \\
\hline 4 & 1.682 & 0 & 0 & 558 \\
\hline 5 & 0 & -1.681 & 0 & 683 \\
\hline 6 & 0 & 0 & 0 & 1000 \\
\hline 7 & 0 & 0 & 1.682 & 699 \\
\hline 8 & 0 & 0 & 0 & 1173 \\
\hline 9 & -1 & -1 & -1 & 703 \\
\hline 10 & -1 & -1 & 1 & 1186 \\
\hline 11 & 1 & -1 & 1 & 531 \\
\hline 12 & 0 & 0 & 0 & 1104 \\
\hline 13 & -1 & 1 & -1 & 1573 \\
\hline 14 & 1 & 1 & -1 & 765 \\
\hline 15 & 1 & 1 & 1 & 462 \\
\hline 16 & 0 & 0 & -1.682 & 897 \\
\hline 17 & -1 & 1 & -1 & 966 \\
\hline 18 & 0 & 0 & 0 & 1055 \\
\hline 19 & -1.682 & 0 & 0 & 903 \\
\hline 20 & 0 & 1.682 & 0 & 1345 \\
\hline
\end{tabular}

\begin{tabular}{llllllll}
\hline Variables & Symbol & Units & \multicolumn{6}{c}{ Coded levels } \\
\cline { 4 - 8 } & & & $\mathbf{- a}$ & $\mathbf{- 1}$ & $\mathbf{0}$ & $\mathbf{+ 1}$ & $\mathbf{+ a}$ \\
\hline $\mathrm{pH}$ & $\mathrm{A}$ & & 6.32 & 7 & 8 & 9 & 9.68 \\
Maltose & $\mathrm{B}$ & $\%$ & -0.01 & 0.25 & 0.5 & 1.0 & 1.26 \\
$\mathrm{NaH}_{2} \mathrm{PO}_{4}$ & $\mathrm{C}$ & $\%$ & -0.02 & 0.01 & 0.06 & 0.1 & 0.13 \\
\hline
\end{tabular}

Table 4 Experimental design and results of CCD

high fibrinolytic activity from various sources (Jeong et al. 2001; Lee et al. 2001; Agrebi et al. 2009). Although fibrinolytic enzymes have been isolated from various organisms, the quest for new fibrinolytic enzymes has not been stopped yet (Mahajan et al. 2012). In this article, a marine isolate Pseudoalteromonas sp. IND11 was subjected to screening and optimizing for fibrinolytic enzyme production. Many organisms from the genus Pesudoalteromonas secreted proteolytic enzymes, for example, Pseudoalteromonas sp. strain CP76 (Porro et al. 2003) and Pseudoalteromonas sp. NJ276 (Wang et al. 2008).

\section{Isolation, screening, and identification of fibrinolytic enzyme producing Pseudoalteromonas sp. IND11}

In the present article, nine fibrinolytic enzymes secreting organisms were isolated from the fish scales, obtained from Arabian sea, $25 \mathrm{~km}$ from Kanyakumari coast, Tamilnadu, India. The extracellular fibrinolytic enzyme production was determined by fibrin plate method. Among the isolates, Pseudoalteromonas sp. IND11 showed more activity; hence this was selected for further studies (Figure 1a). It was Gram - negative, rod - shaped and positive in oxidase test. It showed positivity in tests of catalase and Voges Proskauer and in casein -, and starch - hydrolysis. The strain was negative in tests of nitrate - reduction, urease -, indole -, gas-production and citrate utilization. The isolate 


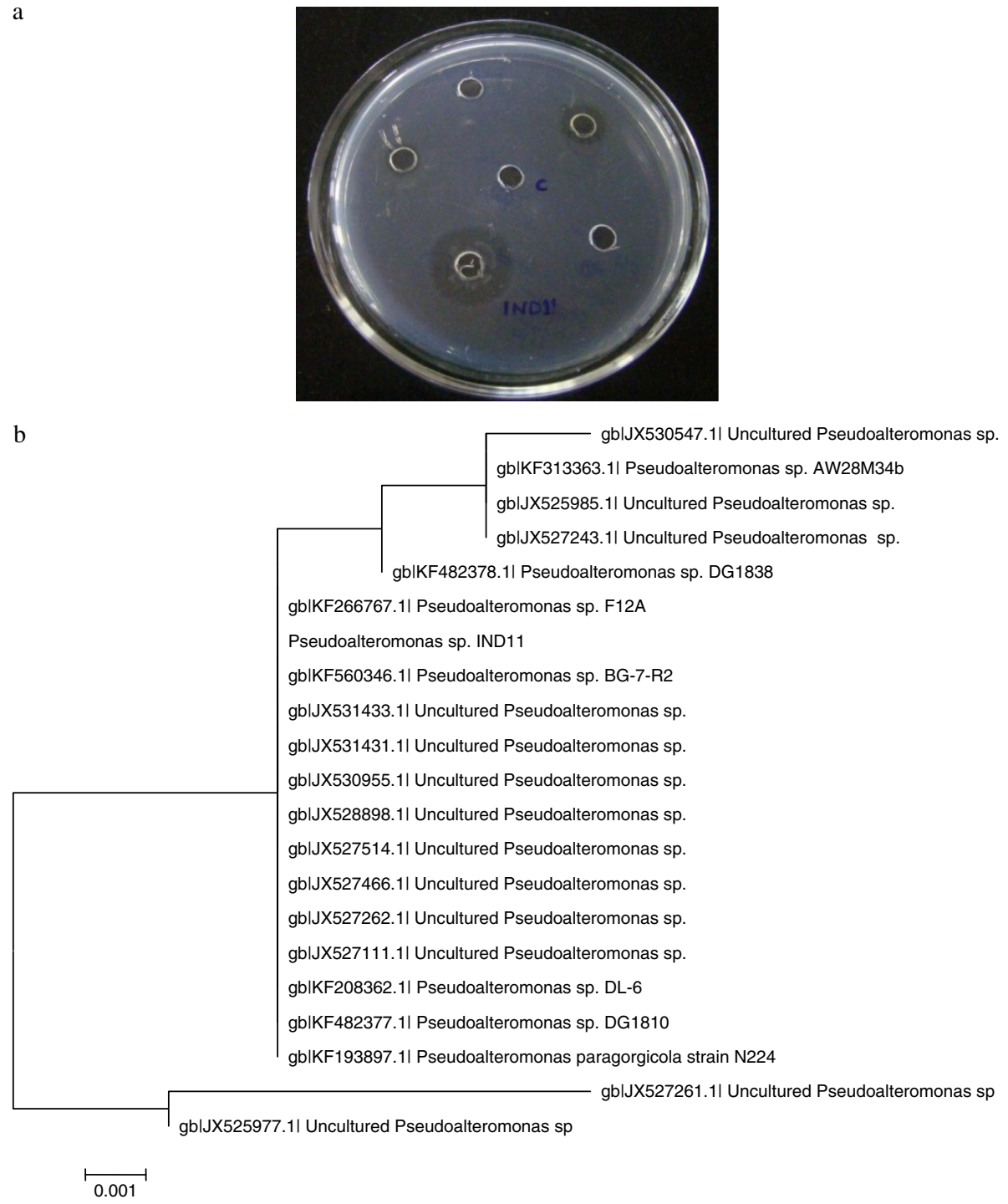

Figure 1 Analysis of fibrinolysis on fibrin-agarose plate (a). Phylogenetic relationships of strain IND11 and other closely related Pseudoalteromonas sp. (b).

was identified as Pseudoalteromonas sp. The $612 \mathrm{bp}$ 16S rDNA sequence of Pseudoalteromonas sp. IND11 has been submitted to the GenBank database and assigned accession number KF683956. A phylogenetic tree was derived from $16 \mathrm{~S}$ rDNA sequences, and it showed the phylogenetic position of Pseudoalteromonas sp. IND11 to closely related species in the genus Pseudoalteromonas (Figure 1b).

\section{Cow dung: a cheap substrate for enzyme production}

This article has showed that cow dung can be used as a solid substrate for fibrinolytic enzyme production. The selection of an ideal substrate for the production of any metabolite is an important factor from an industrial point of view. An ideal substrate should be available throughout the year (Pandey et al. 2000). Reports on SSF of cow dung substrate for the production of fibrinolytic enzyme are limited or, perhaps, not available. Recently, we used cow dung substrate for the production of proteolytic enzymes (Vijayaraghavan and Vincent 2012; Vijayaraghavan et al. 2012), and further now we use the cow dung substarte for fibrinolytic enzyme production. Based on the results obtained from the present article, cow dung is an ideal substrate for fibrinolytic enzyme production. Cow dung substrate supplies nutrients to the microbial culture and anchorage for the growing cells. This is the first report on production of fibrinolytic enzyme from a marine bacterial isolate, Pseudoalteromonas sp. IND11, using statistical experimental design and RSM in optimization of its production under SSF. 
Preliminary screening of nutrients and physical factors for statistical optimization

The microbial strain is unique in their molecular, biochemical, metabolic, and enzyme production properties. Hence, an in-depth knowledge of kinetics and catalytic behavior during protease production from any new strain is a prerequisite for the evaluation of its biotechnological potential (Prakasham et al. 2006). The nutrient factors and physical parameters were optimized to increase fibrinolytic enzyme secretion. The effect of carbon sources was shown in Figure 2a. In this article, among all the supplementary carbon sources $(1 \%[\mathrm{w} / \mathrm{w}])$, maltose has been found to be the best source for fibrinolytic enzyme production. These results were in accordance with reported protease production in the presence of different sugars (Ellaiah et al. 2002). When different concentrations of maltose were added, maltose $(1 \%[\mathrm{w} / \mathrm{w}])$ supported the maximum fibrinolytic enzyme production $(1038 \mathrm{U} / \mathrm{ml})$. It was shown in bacteria that the production of fibrinolytic enzyme was induced by maltose in the culture medium (Liu et al. 2005). The other sources such as glucose, sucrose, xylose, trehalose, and starch also supported fibrinolytic enzyme production. Among nitrogen sources, the addition of casein supported maximum fibrinolytic enzyme production (Figure $2 \mathrm{~b}$ ). When different concentrations of casein were supplemented, casein at $1.5 \%$ supported the maximum fibrinolytic enzyme production $(1006 \mathrm{U} / \mathrm{ml})$. The supplemented casein stimulated fibrinolytic enzyme production. These results are in accordance with the observation made with Bacillus sp. strain AS-S20-1 (Mukherjee and Rai 2011). The sources such as yeast extract, urea, gelatin, beef extract, and peptone also enhanced fibrinolytic enzyme production. In SSF, the addition of inorganic salts enhanced fibrinolytic enzyme production except ammonium chloride.

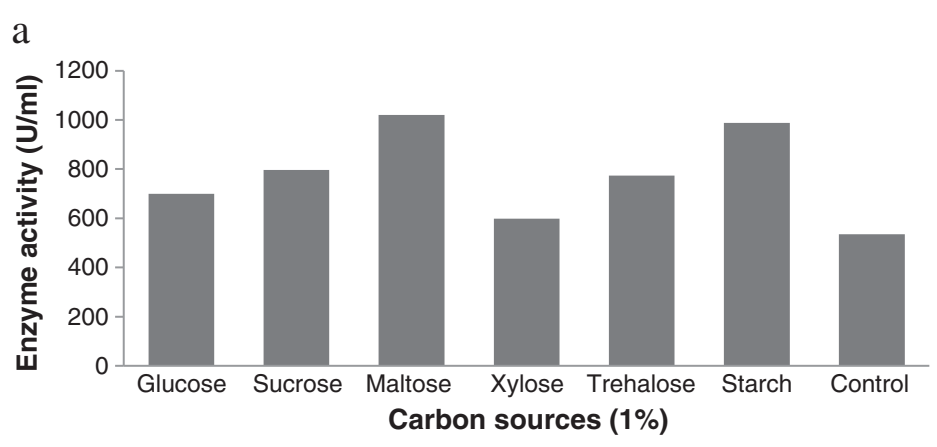

b

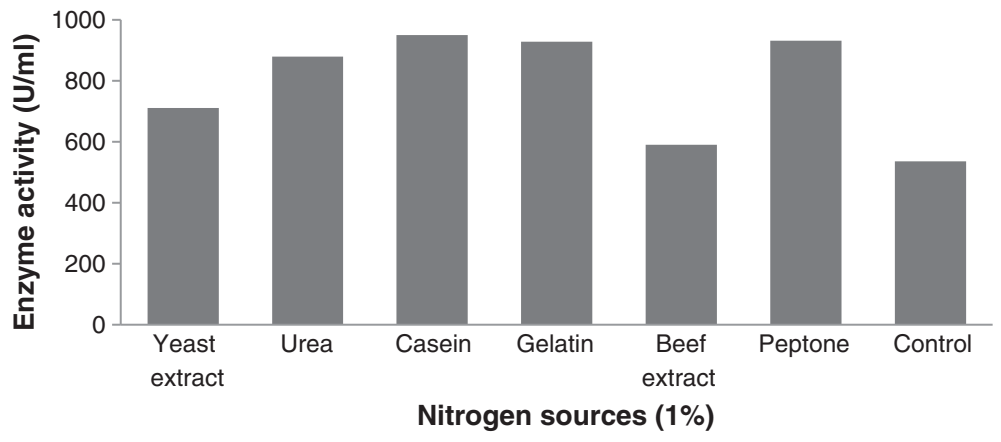

c

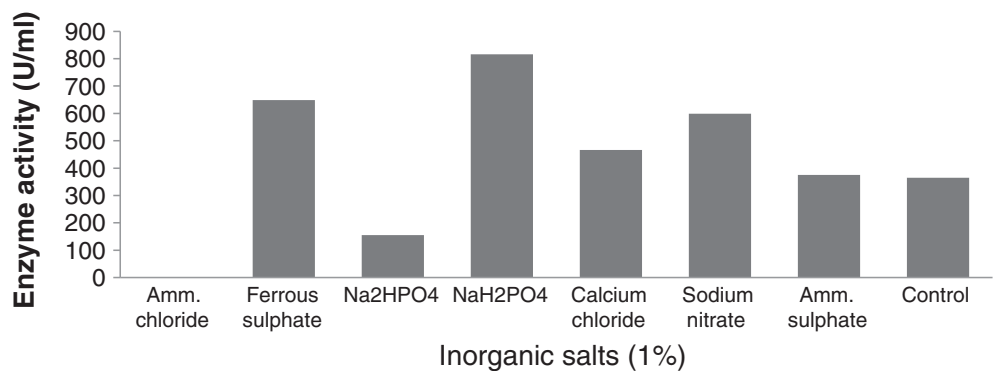

Figure 2 Effect of various carbon (a), nitrogen (b) and inorganic salts (c) on production of fibrinolytic enzymes. 
Among the inorganic salts, sodium dihydrogen phosphate enhanced fibrinolytic enzyme production. These results are in accordance with the observation made with Bacillus subtilis (Artemov and Samuilov 1990). This is because upon translocation across the plasma membrane, serine protease is bound to the outer surface of cell membranes. This bounded protease inhibits extracellular protease synthesis and the metal ions induce the displacement of this enzyme. This could be the possible reason for showing major effect of $\mathrm{Na}^{+}$ion on fibrinolytic enzyme production (Mahajan et al. 2012). Ammonium chloride (1\% [w/w]) totally inhibited fibrinolytic enzyme production (Figure 2c). The repression of the synthesis of protease by excess ammonium has been reported earlier (Kole et al. 1988).

In SSF, moisture content is one of the critical factors for fibrinolytic enzyme production. One-factor-at-a-time experiment revealed that moisture (140\%) significantly affected enzyme production. Among the several factors that are important for microbial growth and enzyme production under SSF, moisture content is a critical factor (Pandey et al. 2000). Alkaline protease production by microbial strains strongly depends on the extracellular $\mathrm{pH}$ (Ellaiah et al. 2002). In the present article, the $\mathrm{pH}$ of the substrate greatly affected enzyme production. Hence, these variables were also selected for statistical optimization experiments.

\section{Two-level full factorial experimental design and an analysis of main effects}

The most significant factors such as $\mathrm{pH}$, moisture, maltose, casein, and sodium dihydrogen phosphate were selected for optimization studies. The matrix developed by the two-level full factorial design and the results were shown in Table 2. The fibrinolytic enzyme production varied from 89 to $1388 \mathrm{U} / \mathrm{ml}$. According to the two-level full factorial design, the optimum medium compositions were as follows: $\mathrm{pH} 8.0,120 \%$ moisture, $0.1 \%$ maltose, $0.5 \%$ casein, and $0.25 \%$ sodium dihydrogen phosphate. The analysis of variance (ANOVA) was used to analyze the main effects and was shown in Table 5 . The model $F$-value of 96.26 implies that the model is significant. There is only

Table 5 ANOVA table for two-level full factorial design

\begin{tabular}{llllll}
\hline Source & Sum of squares & $\mathbf{d f}$ & Mean square & F- Value & p-value \\
\hline Model & $3.777 \mathrm{E}+006$ & 28 & $1.349 \mathrm{E}+005$ & 90.26 & 0.0016 \\
$\mathrm{pH}$ & $5.161 \mathrm{E}+005$ & 1 & $5.161 \mathrm{E}+005$ & 345.36 & 0.0003 \\
Moisture & 10368 & 1 & 10368 & 6.94 & 0.0781 \\
Maltose & 27730 & 1 & 27730 & 18.54 & 0.023 \\
Casein & 4900 & 1 & 4900 & 3.28 & 0.167 \\
NaH ${ }_{2} \mathrm{PO}_{4}$ & 14792 & 1 & 14792 & 9.90 & 0.05 \\
Residual & 4483.37 & 3 & 1493 & & \\
Cor total & $3.781 \mathrm{E}+006$ & 31 & & & \\
\hline
\end{tabular}

a $0.16 \%$ chance that a "Model $F$-value" this large could occur due to noise. Values of "Prob $>F$ " less than 0.05 indicate that model terms are significant. In this model, enzyme production was significantly affected by $\mathrm{pH}(<0.01)$, maltose $(<0.05)$, and sodium dihydrogen phosphate $(<0.05)$. The coefficient estimate was negative to $\mathrm{pH}$, maltose and sodium dihydrogen phosphate. This states that the lower levels of $\mathrm{pH}$ and maltose and sodium dihydrogen phosphate concentrations would benefit fibrinolytic enzyme production. The coefficient estimate was positive to moisture and casein; these indicated that the increase of moisture content and casein concentration in the cow dung medium will support for enzyme production. The "predicted $R$-squared" of 0.865 is in reasonable agreement with the "adjusted $R$-squared" of 0.987 . Adequate precision measures the signal-to-noise ratio. A ratio greater than 4 is desirable. In this model, the ratio of 43.54 indicates an adequate signal. This model can be used to navigate the design space. Neglecting the insignificant variables, the model equation for fibrinolytic enzyme production is as follows:

Final equation in terms of coded factor:

$$
\begin{aligned}
\text { Enzyme activity }= & 686-127 \mathrm{~A}+18 \mathrm{~B}-29 \mathrm{C}+12 \mathrm{D} \\
& -21 \mathrm{E}-78 \mathrm{AB}+14 \mathrm{AC}-133 \mathrm{AE} \\
& -75 \mathrm{BC}-99 \mathrm{BD}+53 \mathrm{BE}+36 \mathrm{CD} \\
& -87 \mathrm{CE}+33 \mathrm{DE}+28 \mathrm{ABC} \\
& -61 \mathrm{ABD}-12 \mathrm{ABE}+23 \mathrm{ACD} \\
& -61 \mathrm{ACE}-121 \mathrm{ADE}-18 \mathrm{BCE} \\
& +79 \mathrm{BDE}-54 \mathrm{CDE}+21 \mathrm{ABCD} \\
& +77 \mathrm{ABCE}-43 \mathrm{ACDE}-39 \mathrm{BCDE} \\
& +65 \mathrm{ABCDE}
\end{aligned}
$$

The three significant factors such as $\mathrm{pH}$, maltose, and casein were further optimized with CCD.

\section{Response surface methodology}

The effect of the three variables $(\mathrm{pH}$, maltose, and sodium dihydrogen phosphate) on fibrinolytic enzyme production was evaluated by CCD and RSM. The CCD model helps to study the interactions between the various variables, and RSM helps to explore the optimum concentrations of each of the variables. The maximum activity of the fibrinolytic enzyme was observed at run 13 (Table 4). The results obtained from CCD were analyzed using ANOVA. The model $F$-value of 6.88 implies that the model is significant (Table 6). There is only a $0.29 \%$ chance that a "Model $F$-value" this large could occur due to noise. Values of "Prob $>F$ " less than 0.05 indicate that model terms are significant. In this case, $\mathrm{A}, \mathrm{B}, \mathrm{AC}, \mathrm{A}^{2}$, and $\mathrm{C}^{2}$ are significant model terms. The second-order polynomial model was used to correlate the independent variables with fibrinolytic enzyme activity. The coefficient of determination $\left(R^{2}\right)$ was calculated to be 0.86 , indicating that the model could explain $86 \%$ of the variability. A value of $>0.75$ indicates appropriate for the model. The "Lack-of-Fit F-value" of 
Table 6 ANOVA for response surface quadratic model

\begin{tabular}{llllll}
\hline Source & Sum of squares & df & Mean square & $\boldsymbol{F}$ Value & $\boldsymbol{p}$-value \\
\hline Model & $1.392 \mathrm{E}+006$ & 9 & $1.546 \mathrm{E}+005$ & 6.88 & 0.0029 \\
$\mathrm{~A}-\mathrm{pH}$ & $4.010 \mathrm{E}+005$ & 1 & $4.010 \mathrm{E}+005$ & 17.83 & 0.0018 \\
B-Maltose & $1.758 \mathrm{E}+005$ & 1 & $1.758 \mathrm{E}+005$ & 7.82 & 0.0189 \\
$\mathrm{C}-\mathrm{NaH} \mathrm{PO}_{4}$ & 44.14 & 1 & 44.14 & $1.963 \mathrm{E}-003$ & 0.9655 \\
$\mathrm{AB}$ & 93312 & 1 & 93312 & 4.15 & 0.069 \\
$\mathrm{AC}$ & $3.925 \mathrm{E}+005$ & 1 & $3.925 \mathrm{E}+005$ & 17.46 & 0.0019 \\
$\mathrm{BC}$ & 5000 & 1 & 5000 & 0.22 & 0.6474 \\
$\mathrm{~A}^{2}$ & $2.075 \mathrm{E}+005$ & 1 & $2.075 \mathrm{E}+005$ & 9.23 & 0.0125 \\
$\mathrm{~B}^{2}$ & 5628.9 & 1 & 5628.9 & 0.25 & 0.6277 \\
$\mathrm{C}^{2}$ & $1.483 \mathrm{E}+005$ & 1 & $1.483 \mathrm{E}+005$ & 6.59 & 0.0280 \\
Residual & $2.249 \mathrm{E}+005$ & 10 & 22485.08 & & 0.1127 \\
Lack of fit & $1.715 \mathrm{E}+005$ & 5 & 34307.37 & 3.22 & Not significant \\
Pure error & 53314 & 5 & 10662.80 & & \\
Cor total & $1.617 \mathrm{E}+006$ & 19 & & & \\
\hline
\end{tabular}

3.22 implies that the lack of fit is not significant relative to the pure error. There is only an $11.27 \%$ chance that a "Lack-of-Fit F-value" this large could occur due to noise. "Adequate precision" measures the signal-to-noise ratio. A ratio greater than 4 is desirable. A ratio of 10.02 indicates the adequate signal. The response $(Y)$ was well fitted with a quadratic second-order polynomial equation.

Final equation in terms of coded factors:

$$
\begin{aligned}
\text { Fibrinolytic activity }(Y)= & +1104-171 \mathrm{~A}+113 \mathrm{~B} \\
& +1.8 \mathrm{C}-108 \mathrm{AB}-221 \mathrm{AC} \\
& +25 \mathrm{BC}-120 \mathrm{~A}^{2}-19 \mathrm{~B}^{2}-101 \mathrm{C}^{2}
\end{aligned}
$$

where $\mathrm{A}$ is the $\mathrm{pH}$ of the substrate, $\mathrm{B}$ is maltose (\%), and $\mathrm{C}$ is sodium dihydrogen phosphate (\%).

The three-dimensional surface plots show the combined effect of two independent variables for fibrinolytic enzyme production, while the third variable was kept at zero-coded level (Figure $3 \mathrm{a}-\mathrm{c}$ ). A perturbation plot compared the effect of the entire factor at a particular point in the design space (Figure 3d). Among the variables used for RSM, medium $\mathrm{pH}$ had a significant effect on fibrinolytic enzyme production compared with other variables. The perturbation graph shows that the factor maltose had a significant role on fibrinolytic enzyme production. Before optimization, the enzyme production was $505 \mathrm{U} / \mathrm{ml}$, and threefold increased enzyme production was achieved after optimizing the medium by RSM. The predicted maximum fibrinolytic enzyme production was estimated to be $1573 \mathrm{U} / \mathrm{ml}$. To validate the experimental design, experiments were conducted in triplicates in optimized conditions, and a fibrinolytic activity of $1610 \mathrm{U} / \mathrm{ml}$ was obtained. This experimental value $(1610 \mathrm{U} / \mathrm{ml})$ is in good agreement with that of the predicted value that validates the model design.
Recently, Al- Nahas et al. (2011) found the fibrinolytic potential of exopolysaccharide synthesized by Pseudoalteromonas spp. from the deep sea sediments. Pseudoalteromonas sp. synthesizes variety of active compounds (Holmstrom and Kjelleberg 1999). The isolate Pseudoalteromonas sp. IND11 grows on cow dung substrate, so it is worthwhile to use cow dung substrate for the production of other useful compounds too. Although fibrinolytic enzyme producing organisms from various marine isolates were reported, only very few reports are available on the secretion of fibrinolytic enzyme by Pseudoalteromonas sp. These kinds of study not only exploit this organism for the optimized production of fibrinolytic enzymes but also help to synthsize other useful compounds.

\section{Optimization and validation}

Validation of the predicted results was done under optimized conditions in three independent experiments. In this model, the experimental fibrinolytic activity of $1365 \mathrm{U} / \mathrm{ml}$ was obtained which correlated to the predicted activity $(1340 \mathrm{U} / \mathrm{ml})$ confirming the rationality of the model. This is 3 fold higher than that obtained before optimization. Thus, overall 3 fold increase in fibrinolytic activity was observed after optimization.

\section{Conclusion}

A fibrinolytic enzyme-secreting Pseudoalteromonas sp. IND11 was grown on cow dung substrate in solid-state culture. The fermentation medium for fibrinolytic enzyme production was optimized using two-level full factorial design and CCD. In the present article, supplementation of $1 \%(\mathrm{w} / \mathrm{w})$ maltose and $0.1 \%(\mathrm{w} / \mathrm{w})$ sodium dihydrogen phosphate increased fibrinolytic enzyme production. The 

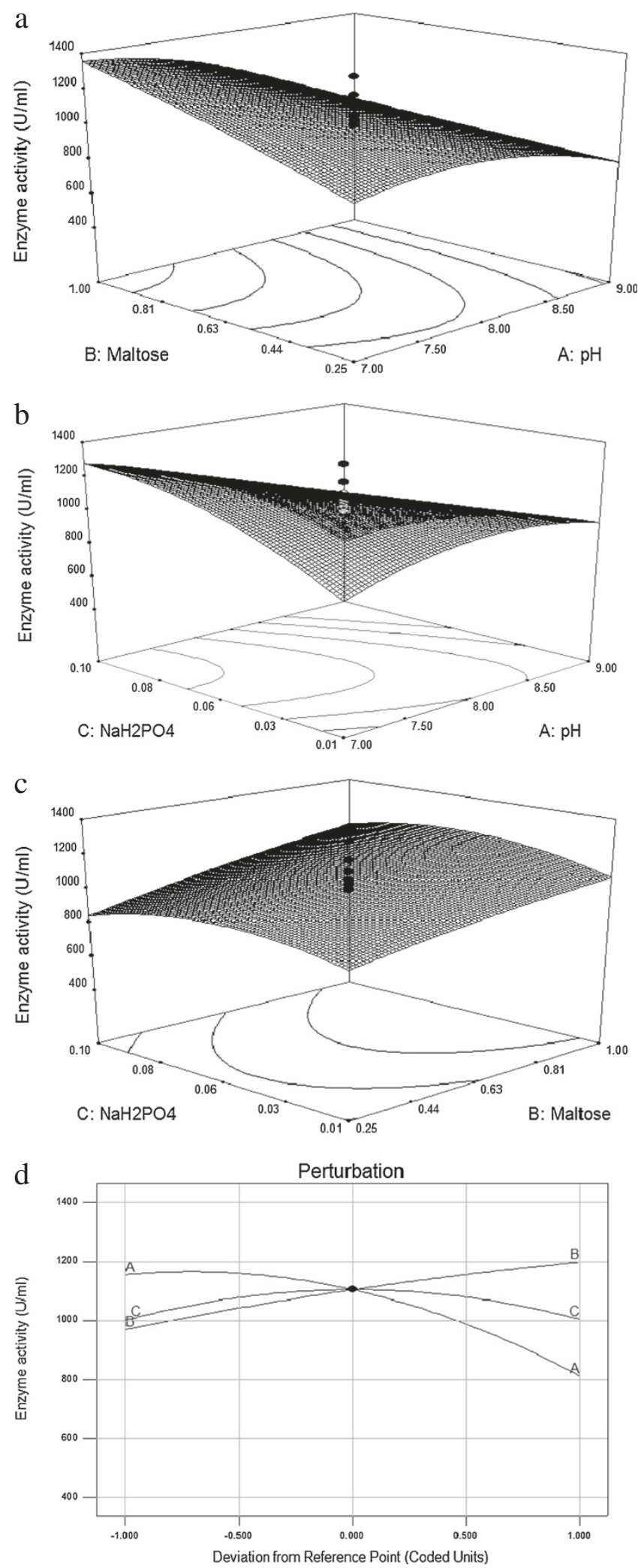

Figure 3 Three dimensional response surface curves showing the effect of interactions of (a) $\mathrm{pH}$ and maltose, (b) $\mathrm{pH}_{\text {and }} \mathrm{NaH}_{2} \mathrm{PO}_{4}(\mathrm{c})$ Maltose and $\mathrm{NaH}_{2} \mathrm{PO}_{4}$ (d) Perturbation graph shows the effect of $\mathrm{pH}\left(\mathrm{a}\right.$ ), maltose (b) and $\mathrm{NaH}_{2} \mathrm{PO}_{4}$. 
optimized medium showed $1573 \mathrm{U} / \mathrm{ml}$ of fibrinolytic activity, which is three times higher than the unoptimized medium.

\section{Competing interests}

The authors declare that they have no competing interests.

\section{Authors' contributions}

PV designed and executed this work. SGPV guided this project work. Both authors read and approved the final manuscript.

\section{Acknowledgements}

The author P. Vijayaraghavan gratefully acknowledges the Council for Scientific and Industrial Research (CSIR), India for providing a Senior Research Fellowship (Ref: 09/652(0024)/2012 EMR-1).

\section{Received: 26 November 2013 Accepted: 23 January 2014} Published: 30 January 2014

\section{References}

Agrebi R, Haddar A, Hmidet N, Jellouli K, Manni L, Nasri M (2009) BSF1 fibrinolytic enzyme from a marine bacterium Bacillus subtilis A26: purification, biochemical and molecular characterization. Process Biochem 44:1252-1259

Al-Nahas MO, Darwish MM, Ali AE, Amin MA (2011) Characterization of an exopolysaccharide-producing marine bacteria, isolate Pseudoalteromonas sp. Afr J Microbiol Res 5:3823-3831

Ansen ML (1939) The estimation of pepsin, trypsin, papain, and cathepsin with hemoglobin. J Gen Physiol 22:78-79

Artemov AV, Samuilov VD (1990) Effect of polyelectrolytes on serine protease secretion by Bacillus subtilis. FEBS Lett 262:33-35

Bode C, Runge M, Smalling RW (1996) The future of thrombolyis in the treatment of acute myocardial infarction. Eur Heart J 17:55-60

Collen D, Lijnen HR (2004) Tissue-type plasminogen activator: a histological perspective and personal account. J Thromb Haemost 2:541-546

Deepak V, Ilangovan S, Sampathkumar MV, Victoria MJ, Pasha SPBS, Pandian SBR, Gurunathan S (2010) Medium optimization and immobilization of purified fibrinolytic URAK from Bacillus cereus NK1 on PHB nanoparticles. Enzy Microb Technol 47:297-304

Demina NS, Veslopolova EF, Gaenko GP (1990) The marine bacterium Alteromonas piscicida-a producer of enzymes with thrombolytic action. Izv Aka Nauk SSSR Biol 3:415-419

Duffy MJ (2002) Urokinase plasminogen activator and its inhibitor, PAl-1, as prognostic marker in breast cancer: from pilot to level 1 evidence studies. Clin Chem 48:1194-1197

Ellaiah P, Srinivasulu B, Adinarayana K (2002) A review on microbial alkaline proteases. J Sci Indust Res 61:690-704

Farid MA, Ghoneimy EA, El-Khawaga N-EA, Awad GEA (2013) Statistical optimization of glucose oxidase production from Aspergillus niger NRC9 under submerged fermentation using response surface methodology. Ann Microbiol 63:523-531

Fujita M, Nomura K, Hong K, Ito Y, Asada A, Nishimuro S (1993) Purification and characterization of a strong fibrinolytic enzyme (nattokinase) in the vegetable cheese natto, a popular soybean fermented food in Japan. Biochem Biophy Res Comm 197:1340-1347

Holmström C, Kjelleberg S (1999) Marine Pseudoalteromonas species are associated with higher organisms and produce biologically active extracellular agents. FEMS Microbiol Ecol 30:285-293

Hong X, Jian-Zhong L, Hai-Yan S, Liang-Nian J (2004) Enhanced production of extracellular ribonuclease from Aspergillus niger by optimization of culture conditions using response surface methodology. Biochem Eng J 21:27-32

Jeong YK, Park JU, Baek H, Park SH, Kong IS, Kim DW (2001) Purification and biochemical characterization of a fibrinolytic enzyme from Bacillus subtilis BK-17. World J Microbiol Biotechnol 17:89-92

Jeong YK, Yang WS, Kim KH, Chung KT, Joo WH, Kim JH, Kim DE, Park JU (2004) Purification of a fibrinolytic enzyme (myulchikinase) from pickled anchovy and its cytotoxicity to the tumor cell lines. Biotechnol Lett 26:393-397

Kole MM, Draper I, Gerson DF (1988) Protease production by Bacillus subtilis in oxygen-controlled, glucose fed-batch fermentations. Appl Microbiol Biotechnol 28:404-408

Lee SK, Bae DH, Kwon TJ, Lee SB, Lee HH, Park JH (2001) Purification and characterization of a fibrinolytic enzyme from Bacillus sp. KDO-13 isolated from soybean paste. J Microbiol Biotechnol 11:845-852
Liu J, Xing J, Chang T, Ma Z, Liu H (2005) Optimization of nutritional conditions for nattokinase production by Bacillus natto NLSSE using statistical experimental methods. Process Biochem 40:2757-2762

Long C, Ou Y, Guo P, Li Y, Cui J, Long M, Hu Z (2009) Cellulase production by solid state fermentation using bagasse with Penicillium decumbens L-06. Ann Microbiol 59:517-523

Lowry OH, Rasebrough NJ, Farr AL, Randall RJ (1951) Protein measurement with folin phenol reagent. J Biol Chem 193:256-275

Mahajan PM, Nayak S, Lele SS (2012) Fibrinolytic enzyme from newly isolated marine bacterium Bacillus subtilis ICTF-1: media optimization, purification and characterization. J Biosci Bioeng 113:307-314

McGrath KG, Zeffre B, Alexander J, Patterson R (1985) Allergic reactions to streptokinase consistent with anaphylactic or antigen-antibody complex-mediated damage. J Allergy Clinical Immunol 76:453-457

Mihara H, Sumi H, Yoneta T (1991) A novel fibrinolytic enzyme extracted from the earthworm, Lumbricus rubellus. Jap J Physiol 41:461-472

Mine Y, Wong AHK, Jiang B (2005) Fibrinolytic enzymes in Asian traditional fermented foods. Food Res Int 38:243-250

Misra RV, Roy RN, Hiraoka H (2003) On farm composting method. FAO, Rome

Montogomery DC (2001) Design and analysis of experiments, 5th edition. John Wiley and Sons, NY

Mukherjee AK, Rai SK (2011) A statistical approach for the enhanced production of alkaline protease showing fibrinolytic activity from a newly isolated Gram-negative Bacillus sp. strain AS-S20-1. New Biotechnol 28:182-189

Olivera NL, Sequeiros C, Nievas ML (2007) Diversity and enzyme properties of protease-producing bacteria isolated from sub-Antarctic sediments of Isla de Los Estados, Argentina. Extremophiles 11:517-526

Pandey A, Soccol CR, Nigam P, Brand D, Mohan R, Roussos S (2000) Biotechnological potential of coffee pulp and coffee husk for bioprocesses. Biochem Eng J 6:153-162

Peng Y, Huang Q, Zhang RH, Zhang YZ (2003) Purification and characterization of a fibrinolytic enzyme produced by Bacillus amyloliquefaciens DC-4 screened from douche, a traditional Chinese soybean food. Comp Biochem Physiol Part B 134:45-52

Porro CS, Mellado E, Bertoldo C, Antranikian G, Ventosa A (2003) Screening and characterization of the protease CP1 produced by the moderately halophilic bacterium Pseudoalteromonas sp. strain CP76. Extremophiles 7:221-228

Prakasham RS, Subba Rao C, Sarma PN (2006) Green gram husk: an inexpensive substrate for alkaline protease production by Bacillus sp. in solid-state fermentation. Bioresour Technol 97:1449-1454

Sabu A (2003) Sources, properties and application of microbial therapeutic enzymes. Ind J Biotechnol 2:334-341

Sneath PHA (1986) Endospore forming gram-positive rods and cocci. In: Sneath PHA, Mair NS, Sharpe ME, Holt JG (ed) Bergey's manual of systematic bacteriology, vol 2. Williams \& Wilkins, Baltimore MD, USA, pp 1105-1238

Sumi H, Hamado H, Tsushima H, et al. (1987) A novel fibrinolytic enzyme (nattokinase) in the vegetable cheese Natto: a typical and popular soybean food in the Japanese diet. Experientia 43:1110-1111

Vijayaraghavan P, Vincent SGP (2012) Cow dung as a novel, inexpensive substrate for the production of a halo-tolerant alkaline protease by Halomonas sp. PV1 for eco-friendly applications. Biochem Eng J 69:57-60

Vijayaraghavan P, Vijayan A, Arun A, Jenisha J, Vincent SGP (2012) Cow dung: A potential biomass substrate for the production of detergent-stable dehairing protease by alkaliphilic Bacillus subtilis strain W. SpringerPlus 1:6. doi: 10.1186/2193-1801-1-76

Wang CT, Ji BP, Li B, Nout R, Li PL, Ji H, Chen LF (2006) Purification and characterization of a fibrinolytic enzyme of Bacillus subtilis DC33, isolated from Chinese traditional Douchi. J Ind Microbiol Biotechnol 33:750-758

Wang QF, Hou YH, XU Z, Miao JL, Li GY (2008) Purification and properties of an extracellular cold-active protease from the psychrophilic bacterium Pseudoalteromonas sp. NJ276. Biochem Eng J 38:362-368

Xiong H, Song L, XU Y, Tsoi MY, Dobretsov S, Qian PY (2007) Characterization of proteolytic bacteria from the Aleutian deep-sea and their proteases. J Ind Microbiol Biotechnol 34:63-71

Zhang H, Sang Q, Zhang W (2012) Statistical optimization of chitosanase production by Aspergillus sp. QD-2 in submerged fermentation. Ann Microbiol 62:193-201

\section{doi:10.1186/2193-1801-3-60}

Cite this article as: Vijayaraghavan and Vincent: Statistical optimization of fibrinolytic enzyme production by Pseudoalteromonas sp. IND11 using cow dung substrate by response surface methodology. SpringerPlus 2014 3:60. 